\title{
The Legal Protection Against Children Through A Restorative Justice Approach
}

\author{
Bimo Bayu Aji Kiswanto*) and Anis Mashdurohatun**) \\ *) Prosecutor's Officer of Republic Indonesia e-mail: bimo.kiswanto@ymail.com \\ ${ }^{* *}$ ) Faculty of Law Universitas Islam Sultan Agung
}

\begin{abstract}
The purpose of this research is to save the future of child offenders who are in conflict with the law. This research is expected to provide a better understanding of the importance of handling child criminal cases outside the formal legal channels to ensure and respect the dignity of the child, the best interests of the child by paying attention to justice for victims Currently, the handling of juvenile criminal cases through Restorative Justice is regulated in Article 52 of Act No. 11 of 2012 concerning the Juvenile Criminal Justice System. The research approach method used is Normative research methods, namely research on criminal law norms contained in Indonesian criminal legislation. The conclusion of this study is that society is expected to be more understanding if children are legal subjects and national assets, as part of the younger generation, children play a very strategic role as the next generation of a nation. In the context of Indonesia, children are the successors to the ideals of a nation's struggle. This strategic role has been recognized by the international community to give birth to a convention which essentially emphasizes the position of the child. A child by nature still has reasoning power that is not yet good enough to distinguish between good and bad things. Crimes committed by children in general are a process of imitating or being influenced by adults.

Keywords: Criminal Cases; Children; Restorative Justice.
\end{abstract}

\section{Introduction}

In Indonesian positive law, a child is defined as a person who is not yet an adult or a person who has not reached a certain age which is stipulated by law as an adult age limit. Children are a mandate as well as a gift from God Almighty, which we must always protect because they have inherent dignity, dignity and rights as human beings that must be upheld.

In terms of national and state life, children are the future of the nation for the next generation of the nation's ideals, so that children have the right to survive, grow, and develop, participate and are entitled to protection from violence, discrimination, and freedom. Children are normal human conditions who are still young and are determining their identity and are very unstable in spirit so they are very easily affected by environmental influences. ${ }^{1}$

Children are legal subjects and national assets, as part of the younger generation, children play a very strategic role as the next generation of a nation. In the context of Indonesia, children are the successors to the ideals of a nation's struggle. This strategic role has been recognized by the international community to give birth to a convention which essentially emphasizes the position of the child. A

${ }^{1}$ Kartini, 1981, Gangguan-Gangguan Psikis, Sinar Baru: Bandung, p. 189. 
child by nature still has reasoning power that is not yet good enough to distinguish between good and bad things. Crimes committed by children in general are a process of imitating or being influenced by adults. ${ }^{2}$

Deviant behavior committed by children/adolescents in the sense of juvenile delinquency is an act or action taken by a person who is not yet an adult who deliberately violates the law and is realized by the child himself that his/her actions may be subject to sanctions or punishment (criminal).

International law has established standards of treatment that each country must and/or can refer to in dealing with children in conflict with the law. International law requires states to provide legal protection and respect for children in conflict with the law through the development of laws, procedures, authorities, and institutions. ${ }^{3}$

The definition of child protection has been clearly regulated in Article 1 number 2 of Act No. 35 of 2014 that: "Child protection is all activities to guarantee and protect children and their rights so that they can live, grow, develop, and participate actively optimally in accordance with human dignity and protection from violence and discrimination".

Limitations regarding the protection of the child, the child needs to be protected from anything that will happen to him. Protection of children in conflict with the law has a fairly broad problem, not only children as victims but also children as perpetrators of crimes as a result of children's actions that result in victims.

Every child has the right to freedom in accordance with the law. Arrest, detention or imprisonment of a child is only carried out if in accordance with applicable law, it can only be done as a last resort. Legal protection of children is an effort to protect the law against various freedoms and human rights of children. ${ }^{4}$

Forms of legal protection for children, such as assistance from community officials, shorter detention periods compared to adults, facilities by law enforcement officers specifically for children, including the separation of juvenile detainees from adult detention is one form of legal protection for children.

Along with the development of the practice of the juvenile criminal justice system that has been implemented so far as regulated in Act No. 11 of 2012 concerning the Juvenile Criminal Justice System. With the presence of Act No. 11 of 2012, it is hoped that it can fill the space of justice as the concept of restorative justice, which is stated in Act No. 11 of 2012, so that the condition of children remains with dignity as their human rights.

Settlement of criminal acts of children in conflict with the law by using the concept of diversion through a restorative justice approach, namely a settlement

\footnotetext{
2Pangestika Rizki Utami, 2018, “Konsep Diversi dan Restorative Justice Sebagai Pergeseran Tanggung Jawab Pidana Pada Sistem Peradilan Pidana Anak", Volkgeist, Vol. 1 No. 1, IAIN Purwokerto: Purwokerto, p. 96.

${ }^{3}$ Guntarto Widodo, 2016, "Sistem Pemidanaan Anak Sebagai Pelaku Tindak Pidana Perspektif Undang-Undang Nomor 11 Tahun 2012 Tentang Sistem Peradilan Pidana Anak", Jurnal Surya Kencana Dua: Dinamika Masalah Hukum dan Keadilan Vol. 6 No.1, Faculty of Law Pamulang University, p. 60.

4Barda Nawawi Arief, 1998, Beberapa Aspek Kebijaksanaan Penegakan dan Pengembangan Hukum Pidana, Citra Aditya Bakti: Bandung, p. 153.
} 
that involves all parties and jointly resolves cases and seeks the best solution to cases faced by children thereby protecting children in conflict with the law which prioritizes the best interests of the child.

According to Muladi, restorative justice is a theory that emphasizes recovering losses caused or incurred by criminal acts. Recovering these losses will be achieved through cooperative processes that include all interested parties. ${ }^{5}$

In principle, restorative justice recognizes three stakeholders, namely victims, perpetrators, and the community in determining the settlement of children's cases. Through restorative justice, there is an effort to bring together victims and perpetrators in order to seek recovery for victims. On the other hand, the perpetrator is burdened with an obligation to account for his actions to the victim and the community and is responsible for admitting his crime and if possible, recovering the suffering of the victim. ${ }^{6}$

From the description of the background above, the purpose of this paper is to be able to find out and answer problems regarding: How is the legal protection for children who are perpetrators of crimes through a restorative justice approach according to Act No. 11 of 2012 concerning the Juvenile Criminal Justice System?

\section{Research Methods}

To answer the writing questions that have been formulated above, the authors will use the normative research method. This research will be descriptive analytical later. Descriptive research is a type of research that provides a description or description of a situation as clearly as possible on the object under study. ${ }^{7}$ It is descriptive, meaning that this research is expected to be able to explain the complete picture of the implementation of Restorative Justice.

Sources and types of data used in this study are secondary data, namely: secondary data, namely data containing primary legal materials, secondary legal materials and tertiary legal materials. The data collection technique in this research is literature study. Literature Study is a technique of collecting data by reviewing the literature and collecting books of written materials, as well as references relevant to this research. After the data from the field is collected using the data collection method described above, the writer will manage and analyze the data using qualitative descriptive analysis. ${ }^{8}$ The data analysis used in this research is qualitative data analysis.

\section{Results and Discussion}

The description of the problems faced by children can be seen as a reason to seek reform of the juvenile criminal justice system, which aims to provide legal protection for children.

\footnotetext{
${ }^{5}$ Muladi, 1995, Kapita Selekta Hukum Pidana, Universitas Diponegoro: Semarang, p. 125. ${ }^{6}$ Rika Saraswati, 2009, Hukum Perlindungan Anak Di Indonesia, Citra Aditya Bakti: Bandung, p. 125. ${ }^{7} J o h n i$ Ibrahim, 2012, Teori dan Metodologi Penelitian Hukum Normatif, Banyumedia Publising: Malang, p. 300.

${ }^{8}$ Bambang Sugugono, 2003, Metode Penelitian Hukum, PT. Raja Grafindo Persada: Jakarta, p. 119.
} 
Juvenile justice reform aims that children in conflict with the law are not justified as guilty children and must be punished as adults who commit crimes. The juvenile criminal justice system is intended to educate children to be better because psychologically it must be understood that the emotional and psychological state of children is still unstable or weak in dealing with the influence of various surrounding environments.

Protection of children in conflict with the law is an effort to protect children and their rights so that they can grow and develop optimally without violence and discrimination. It is increasing, of course, very concerning where the perpetrators are not only adults but are also carried out by children, basically criminal acts committed by children and adults are no different, it's just that the differences can be seen from the perpetrators who are still underage and adults, and the intentions/goals between children and adults in committing a crime are of course also different.

According to the provisions of Article 1 paragraph (3) of Act No. 11 of 2012 provides an age limit for children in conflict with the law, namely: "Children in conflict with the law, hereinafter referred to as children, are children who are 12 (twelve) years old, but under the age of 18 (eighteen) years who are suspected of committing a crime".

In the provisions of Article 3 of Act No. 11 of 2012, states explicitly the rights of children in criminal justice, namely:

- Treated humanely by taking into account the needs according to age;

- Separated from adults;

- Obtain legal and other assistance effectively;

- Carry out relational activities;

- Free from torture, punishment or other cruel, inhuman, and degrading treatment;

- Not sentenced to death or life imprisonment;

- Not arrested, detained, or imprisoned, except as a last resort and for the shortest time;

- Obtaining justice before a juvenile court that is objective and impartial, and in a trial that is closed to the public;

- His identity is not published;

- Obtain assistance from parents/guardians and people who are trusted by the child;

- Obtaining social advocacy;

- Acquire a personal life;

- Gaining accessibility, especially for children with disabilities;

- Obtaining education;

- Obtaining health services; and

- Obtain other rights in accordance with the provisions of the legislation.

The Juvenile Justice System is all elements of the criminal justice system involved in handling cases of juvenile delinquency, namely: ${ }^{9}$

${ }^{9}$ Bernard Arief Sidharta, 1999, Refleksi Tentang Strukutur Ilmu Hukum, Mandar Maju: Bandung, p. 181. 
- Police as a formal institution when juvenile delinquents first come into contact with the justice system, which will also determine whether the child will be released or further processed;

- Prosecutors and parole agencies will also determine whether the child will be released or processed in juvenile court;

- Juvenile court, the stage when the child will be placed in choices, starting from being released to being included in a sentencing institution;

- Punishment institution.

According to Soedarto, juvenile court includes all activities of examining and deciding cases involving the interests of children. The juvenile justice system is aimed at the welfare of the child. This is emphasized in the United Nations Standard Minimum Rules for the Administration of Juvenile Justice that the purpose of juvenile justice is: "The criminal justice system for children/ adolescents will prioritize the welfare of adolescents and will ensure that any reaction to juvenile offenders will always be commensurate with the conditions for both the violators of the law and the violation of the law." 10

The fundamental change in Act No. 11 of 2012 is the use of diversion and restorative justice approaches, the obligation of law enforcement officers to seek diversion at all stages of the legal process.

The function of juvenile justice in general is no different from other courts, namely receiving, examining, adjudicating and resolving cases that are submitted to it, but for juvenile justice, cases handled specifically concern children's cases. The provision of special treatment in order to ensure the physical and mental growth of children as the next generation whose future must be considered, where in this case to provide justice, the judge takes various actions by first examining the truth of the events presented to him.

Judges try to re-enforce laws that have been violated, therefore it is common to say that judges or courts are law enforcers. Courts in adjudicating must be based on applicable law, including written law and unwritten law. Starting from this, in its implementation, this function is carried out by special juvenile justice officials, in other words, this function will not be achieved without the presence of role holders, namely judicial officials.

Starting from this, the purpose of juvenile justice is not only to prioritize the crime as the main element, but protection for the future of children is the target to be achieved by juvenile justice. ${ }^{11}$

The policy of implementing a criminal justice system for children who commit crimes is inseparable from the purpose of protecting and fostering the child concerned, which is more focused on the purpose of improving, rehabilitating, fostering the welfare of the child offender. With an emphasis on child protection, as stated by Sudarto that the activities of examining criminal acts carried out by the police, prosecutors, judges and other officials, are based on principles for the benefit

\footnotetext{
10Pangestika Rizki Utami, op.cit., p. 99.

${ }^{11}$ Agung Wahyono and Siti Rahayu, 1993, Tinjauan Tentang Peradilan Anak di Indonesia, Sinar Grafika: Jakarta, p. 39.
} 
of the child or see what criteria are best for the welfare of the child concerned, without prejudice to attention to the interests of society. ${ }^{12}$

The implementation of the juvenile criminal justice system does not only depend on the role of law enforcement officers, but also depends on the role of community officers, consisting of Community Counselors, Professional Social Workers, and Social Welfare Workers. This change is in line with the paradigm shift in handling children in conflict with the law. ${ }^{13}$

The policy of implementing the criminal justice system for children who commit crimes cannot be separated from the purpose of protecting and fostering the child in question, which is more focused on the purpose of improving, rehabilitating, fostering the welfare of the child offender.

With an emphasis on child protection, as stated by Sudarto, that criminal investigation activities carried out by police, prosecutors, judges and other officials are based on principles for the benefit of the child or see what criteria are best for the welfare of the child concerned, without reduce attention to the public interest. ${ }^{14}$

Child protection has obtained a juridical basis, including the 1945 Constitution of the Republic of Indonesia as the constitutional basis and Act No. 35 of 2014 concerning Child Protection. Article 28B paragraph (2) of the 1945 Constitution of the Republic of Indonesia expressly states: "Every child has the right to survive, grow and develop and has the right to protection from violence and discrimination", while Act No. 35 of 2014 provides a clear and comprehensive arrangement on child protection which principally aims to guarantee and protect children and their rights so that they can live, grow, develop and participate optimally in accordance with human dignity, and obtain protection from violence and discrimination.

In handling and protecting children who are in conflict with the law, the problem is quite extensive, not only as a result of the child's actions that result in victims, but far from that why children commit criminal acts that ultimately harm themselves.

The judicial process that must be taken by the child as a form of accountability for his actions has an impact on the development of the child, the stages of each judicial process starting from the level of investigation, prosecution, trial and guidance in child correctional institutions take quite a long time and do not take much time there are rare deviations and injustices from each of these processes. Children's rights are inherent and protected by law.

The obligations and responsibilities of the state and government for the implementation of child protection are emphasized in Article 21 to Article 25 of Act No. 35 of 2014 which amends Act No. 23 of 2002, which includes obligations and responsibilities:

- Respect and guarantee the human rights of every child regardless of ethnicity, religion, race, class, gender, ethnicity, culture and language, child status, child's birth order and physical and/or mental condition (Article 21);

\footnotetext{
12Pangestika Rizki Utami, op.cit., p. 99-100.

${ }^{13}$ Herlina, 2016, Modul Pembelajaran Gambaran Umum Undang-Undang Sistem Peradilan Pidana Anak, Diklat HAM Kementrian Hukum dan Hak Asasi Manusia RI, Jakarta, p. 11.

${ }^{14}$ Sudarto, 1980, Kapita Selekta Hukum Pidana, Alumni: Bandung, p. 57.
} 
- Provide support for facilities and infrastructure in the implementation of child protection (Article 22);

- Guarantee the protection, maintenance, and welfare of children by taking into account the rights and obligations of parents, guardians or other persons who are legally responsible for children and supervise the implementation of child protection (Article 23);

- Guarantees children to exercise their rights in expressing opinions according to the age and level of intelligence of the child (Article 24).

According to Act No. 11 of 2012, if a child is under 12 years of age commits or is suspected of committing a crime, investigators, community advisors, and professional social workers make decisions to: Submit it back to the parent/guardian; or Include them in education, coaching and mentoring programs; Government agencies or LPKS in agencies that handle the field of social welfare, both at the central and regional levels, for a maximum of 6 (six) months.

Protection of children in conflict with the law can be completed through a judicial process and resolved outside the criminal justice process or known as diversion, where the settlement involves the perpetrator, victim, family of the perpetrator/victim, and other related parties to jointly seek a fair solution by emphasizing restoration to its original state, and not retaliation, which is known as the restorative justice approach.

Act No. 11 of 2012 confirms the obligation for law enforcement officers to seek diversion first by prioritizing special restorative justice for children whose criminal penalties are under 7 (seven) years in resolving child cases. The settlement outside the judicial process is expected to be able to provide a sense of justice to children who are in conflict with the law and by prioritizing the best interests of the child.

The idea of diversion regulated in SMRJJ or The Beijing Rules, stipulates that the idea of diversion can be carried out not only limited to minor crimes against children. The idea of diversion is a form of diversion or waiver of handling juvenile delinquency from the conventional juvenile justice process, towards handling children which is more of a social service nature, and the idea of diversion is carried out to prevent child offenders from the negative impact of the practice of administering juvenile justice ash they were become persistently delinquent. Juvenile justice system processing therefore does more harm than good). ${ }^{15}$

The purpose of diversion in Indonesia, namely to avoid detention, avoid being labeled as evil or labeled as criminals, improve life skills for perpetrators, so that perpetrators are responsible for their actions, prevent repetition of criminal acts, to propose necessary interventions for victims and perpetrators without having to through a formal process, and for a diversion program it will prevent children from following the court system processes. Further steps in this program will keep children away from the negative effects and implications of the judicial process. ${ }^{16}$

\footnotetext{
${ }^{15}$ Romli Atmasasmita, Peradilan Anak di Indonesia, Mandar Maju, Bandung, 2003, p. 201.

${ }^{16}$ Apong Herlina et.all, 2004, Perlindungan Terhadap Anak Yang Berhadapan Dengan Hukum Manual Pelatihan Untuk Polisi, POLRI- UNICEF: Jakarta, p. 330.
} 
The definition of restorative justice according to Muladi basically has similarities with the definition formulated by Prison Fellowship International, namely: "Restorative justice is a theory of justice that emphasizes repairing the harm caused by criminal behavior. It is best accomplished when the parties themselves meet cooperatively to decide how to do this. This can lead to the transformation of people, relationships and communities". ${ }^{17}$

Restorative justice is a diversion process, namely all parties involved in a particular crime together to overcome problems and create an obligation to make things better by involving victims, children, communities and related parties to find the best solution for children without any retaliation.

Settlement of cases of children in conflict with the law by using a restorative justice approach, a settlement that involves all parties and jointly resolves cases and seeks the best solution to cases faced by children. Thus, protection of children in conflict with the law prioritizes the best interests of children. Restorative justice is the most recommended form of diversion of children in conflict with the law. This is because the concept of restorative justice involves various parties to resolve a problem related to criminal acts committed by children.

The diversion system is a pathway for resolving criminal cases outside the formal legal process which is based on the concept of restorative justice. Both have similar characteristics in terms of solving criminal problems through deliberation involving victims, perpetrators, law enforcement officers, and the community.

Diversion in Act No. 11 of 2012 is a restorative justice process. That is, in the implementation of the diversion, all parties take part in resolving the child's case against the crime that has been committed in the best interest of the child.

Legal protection for children through the application of restorative justice is an effort to protect the law against various freedoms and human rights of children as well as various interests related to child welfare.

Restorative justice has an important meaning in the settlement of crimes involving children. The restorative criminal justice process holds the view that realizing justice is not only a matter for the government and the perpetrators of crime, but more than that it must provide justice in totality that cannot ignore the interests and rights of victims and the community.

Restorative justice aims to realize the recovery of the conditions of crime victims, perpetrators, and interested communities through a case settlement process that does not only focus on trying and punishing perpetrators, especially cases involving children. In the sense that restorative justice makes a map of the interests and roles of each, both victims, perpetrators of crimes, and related communities, so that there is a basis for distributing responsibility for crimes in accordance with their respective positions and roles, in order to achieve quality justice and restore .

\section{Closing}

Legal protection for children who are perpetrators of criminal acts through a restorative justice approach according to Act No. 11 of 2012 concerning the

${ }^{17}$ Muladi, op.cit., p. 126. 
Juvenile Criminal Justice System is an effort to protect children and their rights so that they can grow and develop optimally without violence and discrimination. The fundamental change in Act No. 11 of 2012 is the use of diversion and restorative justice approaches, the obligation of law enforcement officers to seek diversion at all stages of the legal process. Diversion is the resolution of cases involving perpetrators, victims, families of perpetrators/ victims, and other related parties to jointly seek a fair solution by emphasizing recovery back to its original state.

Handling children's criminal cases through restorative justice will be carried out optimally, if the completeness of restorative justice is available properly in a district court, for example there is a children's waiting room, children's courtroom, mediation room. Thus, restorative justice is really carried out for the best interests of the child.

\section{References}

\section{Journal}

[1] Guntarto Widodo, March 2016, "Sistem Pemidanaan Anak Sebagai Pelaku Tindak Pidana Perspektif Undang-Undang Nomor 11 Tahun 2012 Tentang Sistem Peradilan Pidana Anak", Jurnal Daulat Hukum: Faculty of Law, Universitas Islam Sultan Agung.

[2] Pangestika Rizki Utami, June 2018, "Konsep Diversi dan Restorative Justice Sebagai Pergeseran Tanggung Jawab Pidana Pada Sistem Peradilan Pidana Anak", Jurnal Daulat Hukum: Faculty of Law, Universitas Islam Sultan Agung.

\section{Book}

[1] Agung wahyono and Siti Rahayu, 1993, Tinjauan Tentang Peradilan Anak di Indonesia, Sinar Grafika: Jakarta.

[2] Apong Herlina dkk, 2004, Perlindungan Terhadap Anak Yang Berhadapan Dengan Hukum Manual Pelatihan Untuk Polisi, POLRI- UNICEF: Jakarta.

[3] Barda Nawawi Arief, 2001, Beberapa Aspek Kebijakan Penegakan dan Pengembang-an Hukum Pidana, Citra Aditya Bakti: Bandung.

[4] Bernard Arief Sidharta, 1999, Refleksi Tentang Strukutur Ilmu Hukum, Mandar Maju: Bandung.

[5] Herlina, 2016, Modul Pembelajaran Gambaran Umum Undang-Undang Sistem Peradilan Pidana Anak, Diklat HAM Kementrian Hukum dan Hak Asasi Manusia RI: Jakarta.

[6] Kartini, 1981, Gangguan-Gangguan Psikis, Sinar Baru: Bandung.

[7] Muladi, 1995, Kapita Selekta Hukum Pidana, Universitas Diponegoro: Semarang.

[8] Rika Saraswati, 2009, Hukum Perlindungan Anak Di Indonesia, Citra Aditya Bakti, Bandung,

[9] Romli Atmasasmita, 2003, Peradilan Anak di Indonesia, Mandar Maju: Bandung,

[10] Sudarto, 1980, Kapita Selekta Hukum Pidana, Alumni: Bandung.

[11] Apong Herlina dkk, 2004, Perlindungan Terhadap Anak Yang Berhadapan Dengan Hukum Manual Pelatihan Untuk Polisi, POLRI- UNICEF: Jakarta

[12] Sudarto, 1980, Kapita Selekta Hukum Pidana, Alumni: Bandung 